\title{
Dreigt ons polderlandschap verloren te gaan?
}

\section{Barbara Majoor}

De afgelopen jaren is door de beroepsorganisatie en de overheid hard gewerkt om het landschap van onze beroepsregelgeving opnieuw in te richten. Dat is gelukt en met een snelheid waar menig stedenbouwkundige jaloers op zou zijn. Maar is het een herkenbaar landschap voor de

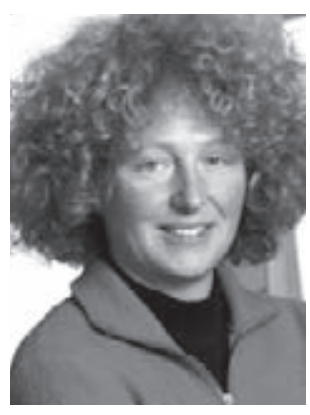
professional en kan die hierin zijn weg wel vinden? Gevoelens van 'te weinig' herkenning en 'te zware' regeldruk voeren de boventoon. De roep om deregulering vanuit een deel van de collega's is enorm. Er worden voorstellen gedaan om regelgevende kaders, kwaliteitsregels en gedragsregels moeiteloos op de brandstapel te gooien. Fantasierijke voorstellen worden en zijn gedaan om groepen accountants onder de noemer accountants in business in de VGC te schuiven en nieuwe begrippen te introduceren. Dit laatste wordt bijvoorbeeld pijnlijk zichtbaar bij de voorstellen van de Redactiecommissie NOvAA/ NIVRA om via de introductie van het begrip 'besloten verkeer' een groep collega's een plekje te geven in het landschap waar zij, gegeven de aard van hun dienstverlening, totaal niet thuis horen. Dit alles heeft als effect dat ons landschap ernstig dreigt te verrommelen. De samenhang en structuur; de eens zo kenmerkende eigenschappen van ons landschap van regels dreigt zo verloren te gaan. De vraag komt op wat er nu eigenlijk speelt in de Nederlandse polder. Speelt het aloude gevoel van het kwijtraken van de

Prof. Dr. G.C.M. Majoor RA is hoogleraar aan Nyenrode Business Universiteit, partner bij het Department of Professional Practice van KPMG en lid van de International Ethics Standards Board Accountants (IESBA) van het IFAC. grip op de totstandkoming van de regelgeving ons parten? Is het poldermodel in het gedrang?

Wij moeten beseffen dat het hedendaagse landschap van regelgeving een cultuurlandschap is. Dit landschap wordt tot stand gebracht door een krachtenspel tussen de individuele beroepsbeoefenaar, de beroepsorganisatie, de overheid en de gebruiker. Elk van deze krachten heeft zo zijn eigen dimensie en staat voor een wereld op zichzelf. Maar dat wil niet zeggen dat de individuele beroepsbeoefenaren geen grip en invloed meer kunnen uitoefenen op de totstandkoming van dat landschap. Hiervoor is echter het poldermodel - dat zich kenmerkt door een overlegstructuur met uitsluitend de eigen collega's via afstemming in commissies, ledenbijeenkomsten en instemming op een ledenvergadering - geen levensvatbare variant meer.

De afgelopen jaren is duidelijk geworden dat de beroepsorganisatie en de overheid nadrukkelijk over de landsgrenzen heenkijken bij de inrichting van nieuwe regelgeving en hierin een bewuste keuze hebben gemaakt. Zij hebben daarmee ons polderlandschap een internationaal karakter gegeven en daarmee in feite het bovengeschetste poldermodel opgegeven. De overlegstructuur die zo kenmerkend is voor het poldermodel lijkt minder zichtbaar in de internationale totstandkoming van regelgeving, maar is zeker wel aanwezig. Internationaal is binnen de IFAC het poldermodel juist behoorlijk stevig vorm gegeven. Ik kan dat uit eigen ervaring bevestigen. De besluitvorming in bijvoorbeeld de International Ethics Standards Board for Accountants (IESBA) is een weerspiegeling van de belangen van alle vier de partijen: gebruikers, regelgevers, accountantsorganisaties en individuele professionals. Deze hebben allemaal hun inbreng via enerzijds directe vertegenwoordiging en anderzijds consultatieprocedures. Dus het is de uitdaging voor het NIVRA en NOvAA om 
een nieuwe overlegstructuur in te richten waardoor het poldermodel een nieuw leven krijgt met een internationale uitstraling die zichtbaar is voor de individuele beroepsbeoefenaar. Deze nieuwe overlegstructuur vereist een proactieve inbreng van alle geledingen van het beroep om een mening te vormen die vervolgens kan worden ingebracht in internationale gremia. Hierbij wil ik opmerken dat het hebben van Nederlandse vertegenwoordiging in internationale standard-setting commissies daarin behulpzaam is, maar geen nadrukkelijke noodzaak. En evenmin is een vertegenwoordiging 'alleen' niet de invulling van het nieuwe poldermodel.
Ten slotte de gebruiker, een naar mijn mening onbelichte kracht, die thans nog te weinig aandacht krijgt in het huidige Nederlandse poldermodel. Ik wil ervoor pleiten om de mening van gebruikers nadrukkelijker een plaats te geven in de discussies die binnen het Nederlandse accountantsberoep worden gevoerd over regeldruk et cetera. Ons bestaansrecht is immers verbonden aan het maatschappelijke belang van onze functie en daarin heeft de gebruiker altijd het laatste woord. 